\title{
LA EDAD MEDIA EN LA PENÍNSULA IBÉRICA. LA RECONQUISTA A TRAVÉS DE MAPAS VIVOS: UN USO PRÁCTICO DE LAS TIC DENTRO DE LA HISTORIA
}

\author{
Francisco Javier Sánchez Sansegundo \\ Moussa Boumadan Hamed \\ Universidad Autónoma de Madrid \\ Ángel Gozalo Mandrión \\ Hp Educación España y Grupo AE
}

\section{RESUMEN}

Este trabajo se trata de un proyecto de innovación en la materia de Ciencias Sociales de $2^{\circ}$ de la ESO, sobre la Reconquista en la Península Ibérica. En él proponemos la creación de un atlas histórico mediante filosofía maker y aprendizaje colaborativo. Los alumnos serán quienes desarrollen la actividad, una vez hayan investigado sobre el tema. Dentro de las nuevas tendencias del uso de las Tecnologías de la Información y la Comunicación (TIC) en la educación no podemos olvidarnos de los entornos que emulan la realidad y que actualmente están cada vez más presentes. El empleo de las TIC en este tema nos ayudará a que los alumnos consigan afianzar mucho más los conceptos, pues al realizar ellos una labor de investigación y de participación en la construcción de los contenidos, el nivel de retención de los mismos será mucho mayor.

\section{PALABRAS CLAVE \\ Innovación - Tecnología - Historia - Reconquista - Mapas}

\begin{abstract}
This work is a tribute to an innovation project in the field of Social Sciences of the 2nd ESO, on the Reconquest in the Iberian Peninsula. We propose the creation of a historical atlas through maker philosophy and collaborative learning. The students will develop the activity. Within the new trends in the use of Information and Comunication Technologies (ICT) in education, we don't forget of the environments that emulate reality. The use of ICTs in this topic helped us to get students to consolidate the concepts much more, so to carry out research and participation in the construction of content, the level of retention will be much greater.
\end{abstract}

KEY WORDS

Innovation - Technology - History - Reconquest - Maps 